\title{
Downstream development strategy of processing industry in Jambi Province
}

\author{
Erni Achmad*; M. Rachmad. R; Zamzami; Arman Delis
}

Doctoral Program in Economics, Postgraduate, Universitas Jambi, Indonesia

*To whom correspondence should be addressed. Email: erniachmad24@gmail.com

\begin{tabular}{|l|l|l|l|l|}
\hline DOI: & Received: & Revised: & Accepted: & Published: \\
10.22437/ppd.v8i5.10491 & 15.09 .2020 & 27.12 .2020 & 29.12 .2020 & 31.12 .2020 \\
\hline
\end{tabular}

\begin{abstract}
The food and beverage industry, the paper and paper goods industry, and the rubber industry, rubber and plastic goods are leading industries that play an important role in the regional economy of Jambi Province. Therefore, policies are needed to sustain leading industries' growth and development. This research aims to formulate a downstream strategy for the leading processing industry in Jambi province. The method used is the Analytical Network Process (ANP). The analysis results show that the priority strategy in the downstream development of the three leading industries in Jambi Province is optimizing the government's role in policy and funding for the downstream program.
\end{abstract}

Keywords: Leading industry, Downstream, ANP

JEL Classification: C02, O14, O25

\section{INTRODUCTION}

The manufacturing sector has a vital role in development. The industrial sector has advantages over other sectors with substantial capital values, the ability to absorb a large labor force, and the ability to create added value from each input or raw ingredients that are processed (Nila, 2014). Some regions have shown significant developments in the manufacturing industry's contribution to their economy, resulting in a change in the economy's structure from agriculture to the manufacturing sector. (Desfiando, 2014)

According to statistics (BPS), in 2019, the industrial sector's growth has decreased from $4.27 \%$ to $3.8 \%$, where the industry's contribution was expected to be substantial in boosting economic growth, reducing poverty, and job creation to reduced unemployment. This decline in the contribution and growth of the industrial sector leads to a symptom of de-industrialization. Suppose the decline in the contribution of the industrial sector in Indonesia continues. In that case, the industrial sector can no longer be expected to be a driving force and play an essential role in the Indonesian economy in the future.

The province of Jambi consists of nine districts and two cities with various commodities scattered in these areas. Each district has natural resources, namely in several commodities supported by a reasonably large area. Jambi Province has been known to have three sub-sectors of the leading processing industry, which affect the regional economy, namely the food and beverage industry, the paper and paper products industry, and the rubber industry, rubber, and plastic products (Fauzi et al., 2019; Hardiwan et al., 2019). In terms of morphological growth, the three leading processing industries have significantly contributed to increasing economic growth and GDRP Jambi 
Province formation. So it is indispensable to pay attention and be given encouragement for the development of its downstream.

For this reason, the progress of the regional economy in the future, the process of developing the processing industry in a planned and systematic manner, in this case, is the downstream development of the processing industry which will encourage the role of the manufacturing sector as the main source of regional economic growth in Jambi province. There are many downstream industry problems in the regions, including roads, availability of electrical energy sources, markets, quality workforce, regional security stability, well-managed natural resources, the industry's raw materials, and a good investment climate. In this regard, the Jambi provincial government is trying to optimize its potential with the regional development plan's industrial downstream target. It reduces social inequality and environmental sustainability, thus encouraging the government's role in managing diversity (Pike et al., 2013).

Based on the conditions, strategic steps are needed to overcome existing problems and increase the downstream industry's development in Jambi Province. The selection of strategic steps is made with clear priorities. All industrial stakeholders, including the Jambi Provincial Government, can make a real contribution to the processing industry's development.

\section{METHODS}

The types of data used in this study are secondary and primary data. Primary data is sourced by gathering experts or experts in a group discussion forum, questionnaires, and in-depth interviews with representative experts and practitioners who understand the issues discussed downstream industry Jambi district and province. Secondary data sourced from the Jambi Province Central Bureau of Statistics, Jambi Province Regional Development Planning Agency, Jambi Province Industry and Commerce Office, and the Jambi Province Plantation Office.

The technique of determining experts is carried out using the purposive sampling method (Andi et al. 2017), which is deliberately selecting experts who are competent and directly involved with the processing industry in Jambi Province, which consists of the local government as regulators, practitioners, academics and industry experts. The details of the list of experts who became sources are shown in Table 1.

Table 1. The list of experts in the research

\begin{tabular}{clc}
\hline No & \multicolumn{1}{c}{ Institutions } & Number of experts \\
\hline 1 & Jambi Province Regional Development Planning Agency & 1 \\
2 & Jambi Province Industry and Trade Office & 2 \\
3 & Jambi Provincial Plantation Office & 1 \\
4 & Department of Agriculture and Food Security of Jambi & 1 \\
5 & Hok Tong Crumb Rubber Jambi & 1 \\
6 & Head of Investment DPMPTSP Jambi Province & 1 \\
7 & Jambi University Economics Expert & 1 \\
8 & Food and Beverage Business Actors & 1 \\
9 & PT BGR (CPO) Jambi & 1 \\
10 & PT Lontar Papyrus Pulp and Paper & 2 \\
\hline & Total & $\mathbf{1 2}$ \\
\hline
\end{tabular}

The method used in this research is the Analytical Network Process (ANP) method. The ANP analysis model is a mathematical theory that can analyze the effect using an assumptive approach to solve the problem. ANP depends on the alternatives and existing criteria (Saaty, 2005). This ANP method attempts to explain the technical 
analysis of using pairwise comparisons on alternatives and project criteria. Then in the ANP network, the level in ANP is called a cluster, which can have criteria and alternatives in it.

The Analytic Network Process (ANP) is carried out at several stages, namely:

1. Model construction is compiled based on theoretical and empirical literature reviews and questions experts and industry practitioners. It conducts interviews through indepth interviews to study and discuss in more depth to obtain the real problem.

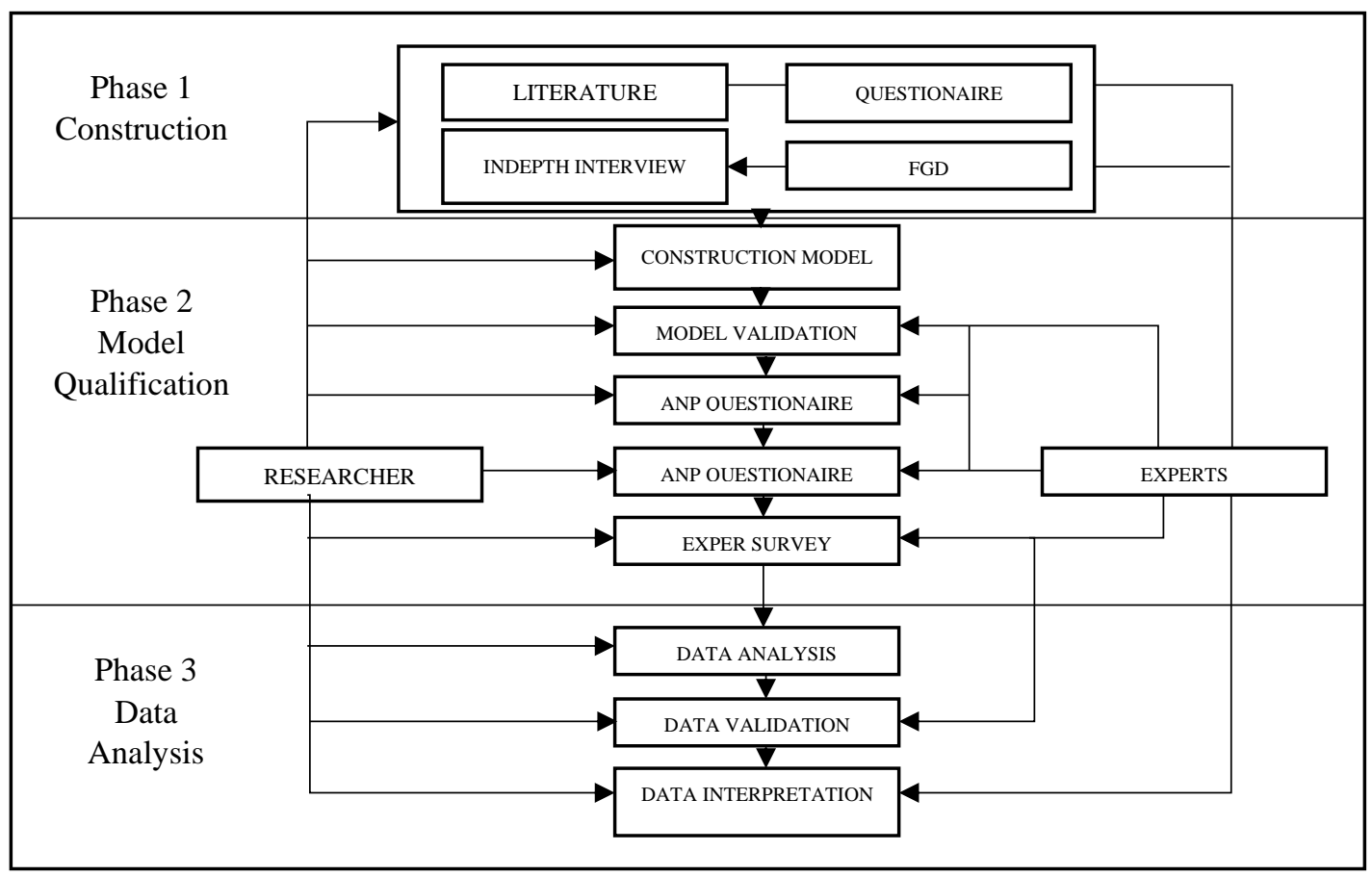

Figure 1. The stages of research with ANP

Source: Ascarya in Rusydiana (2013)

2. Model quantification, the stage of quantifying the model using questions that have been compiled in the ANP questionnaire, namely in the form of pairwise comparisons between elements in the cluster to the respondents. This questionnaire is distributed to respondents to determine which of the two is more influential (more dominant) (a numerical scale of 1-9). The data from the assessment results are then collected, and input through the super decision software to be processed to produce a supermatrix form. The results of each respondent will be inputted on a separate ANP network. In the grading process, problems may arise in the consistency of pairwise comparisons. The consistency ratio provides a numerical assessment of how inconsistent these evaluations may be. If the calculated ratio is less than 0.10 , consistency is considered satisfactory.

3. Synthesis and Analysis

\section{a. Geometric Mean}

In this stage, the objective of calculating and knowing the results of individual assessments of respondents and determining the results of opinions in one group is carried out by calculating the geometric mean (Rusydiana, 2013). Questions in the form of comparison (Pairwise Comparison) of the respondents will be combined to form a consensus. The geometric mean is a type of average calculation that shows a certain tendency or value which has the following formula:

$$
\mathrm{GM}=(\mathrm{R} 1 * \mathrm{R} 2 * \mathrm{R} 3 * \ldots * \mathrm{Rn}) 1 / \mathrm{n}
$$




\section{b. Rater Agreement}

The next step is to measure the Rater Agreement, what is meant by the rater agreement is a measure that shows the level of conformity (agreement) of the respondents $(\mathrm{R} 1-\mathrm{Rn})$ to a problem in one cluster. The tool used to measure the rater agreement is Kendall's Coefficient of Concordance (W; $0<\mathrm{W} \leq 1)$. W $=1$ indicates a perfect fit (Rusydiana, 2013). If the test value of $\mathrm{W}$ is $1(\mathrm{~W}=1)$, it can be concluded that the assessment or opinion of the respondents has a perfect fit. If W's value is 0 or getting closer to 0 , it indicates a mismatch between the respondents' answers or the answers vary (Ascarya in Rusydiana, 2013). In this ANP model, there are three basic principles (Mardiyantoni, 2012), namely: Decomposition, Comparative Judgments, and Hierarchical Composition or synthesis of priorities:

1. The decomposition principle is applied to structure complex problems into a hierarchical framework or ANP framework consisting of cluster networks.

2. The comparative assessment principle is applied to construct pairwise comparisons of all combinations of elements in the cluster seen from the parent cluster. This pair comparison is used to get the local priority of elements in a cluster, as seen from the parent cluster.

3. The principle of hierarchical composition or synthesis is applied to multiply the local priority of elements in the cluster by the "global" priority of the parent element, resulting in the entire hierarchy's global priority.

ANP is used and applied to complex, complex decision making that requires various interactions and dependencies. As a development method of the AHP (Analytic Hierarchy Process) method, ANP still uses the Pairwise Comparison Judgment Matrices (PCJM) between similar elements. ANP pairwise comparisons are made between elements in components or clusters for each interaction in the network. Pairwise comparison using a numeric scale of 1-9 is a translation of the verbal assessment shown in Table 2.

Table 2. Comparison of verbal and numeric scales

\begin{tabular}{cl}
\hline Level of Importance & Definition \\
\hline 9 & Very, very much influence \\
7 & Very big influence \\
5 & Bigger influence \\
3 & It's a little bit bigger \\
1 & Equally influential \\
$2,4,6,8$ & Middle value among adjacent considerations \\
\hline
\end{tabular}

Source: Saaty, 2005

\section{RESULTS AND DISCUSSION}

The development strategy model for the downstream processing industry in Jambi Province and the alternative strategies that have been determined are shown by the model formed in Figure 2 using super decision software. The model is also feedback, where each arrow always points up and down (back and forth). The network can depend on the cluster but can also depend on strategy. Meanwhile, feedback increases priority and makes predictions more accurate (Azis, 2003). Therefore, ANP results are expected to be more stable.

Figure 2 explains that the purpose of developing this model is to comprehensively determine the downstream strategy of the leading processing industry in Jambi Province in order to obtain the right strategy to increase the downstream industry. The model consists of 3 clusters consisting of factors, problems, and strategies. The factors are divided into 4, namely resources, economy, social, and local government policies. 


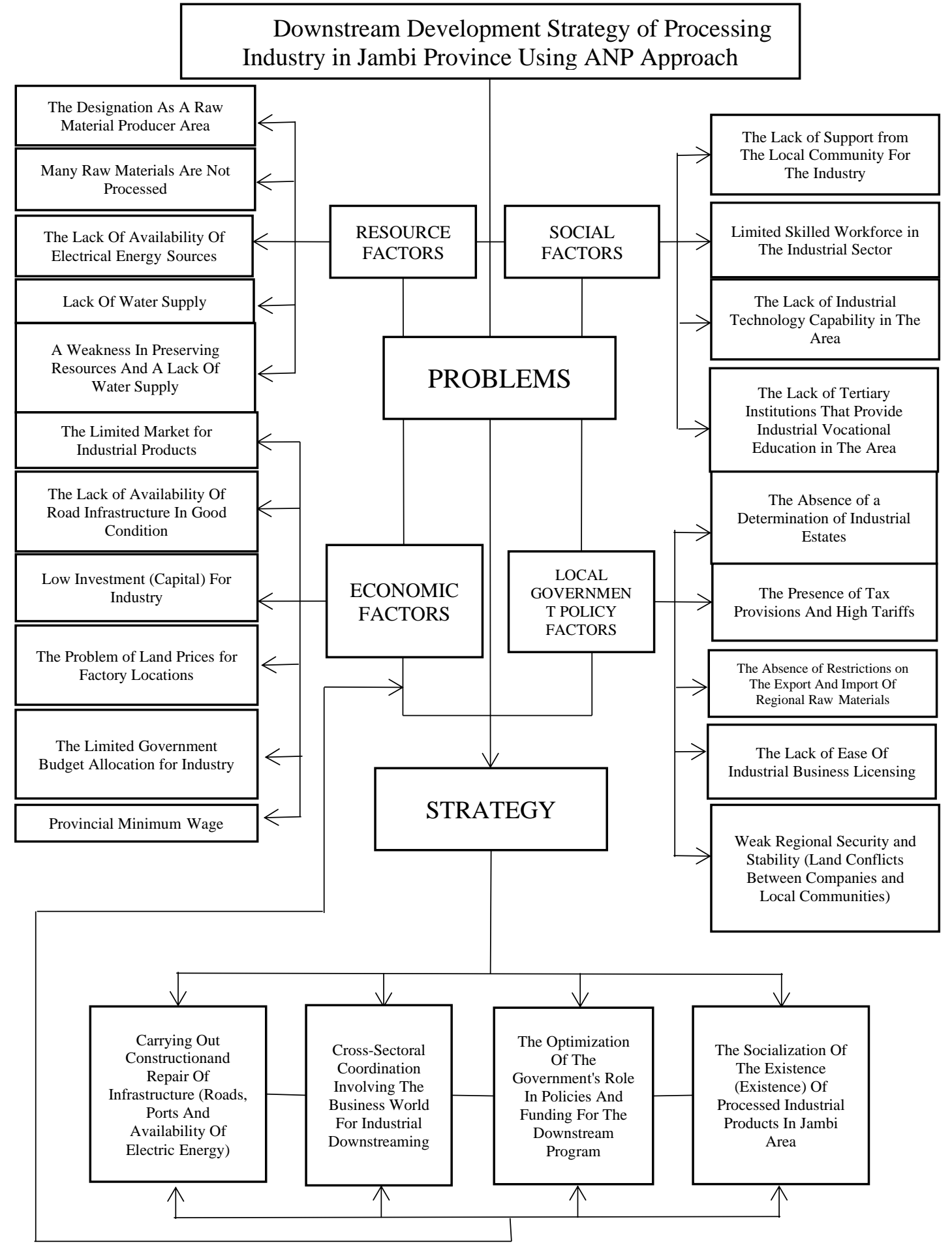

Figure 2. Structure of research models using Software Super Decision

Figure 2 also divides the strategy for the downstream problems of the leading processing industry in Jambi Province into four strategies. These strategies are undertaking infrastructure development and improvement (roads, ports, and availability of electrical energy), cross-sectoral coordination involving the business world for industrial downstream, optimizing government role in policies and funding for industrial downstream programs, and socializing the existence of local industrial processed products - Jambi through promotional media. 
Super decision software presents the conclusion's results based on the average value to determine the overall priority order and the synthesis results for each respondent based on the existing categories. For more details, the following describes how each criterion and strategy's synthesis results in the ANP process. At this stage, the results will show the overall geometric mean and rater agreement level using a measure of Kendall's coefficient of concordance (W) (Lucke \& Rowe, 2006).

\section{Factor cluster synthesis}

Figure 3 shows the results of the factor cluster. It can be seen that the rater agreement value is $38.06 \%$. It means that the respondents' level of agreement on the priority cluster order of factors in the form of Regional Government, Economic, Resources, and Social Policies is $38.06 \%$. Based on respondents' combined value, each priority order of determining the downstream strategy is government policy at $39.40 \%$, followed by economic factors at $24.46 \%$. Then the resource and social factors were $19.39 \%$ and $16.75 \%$, respectively.

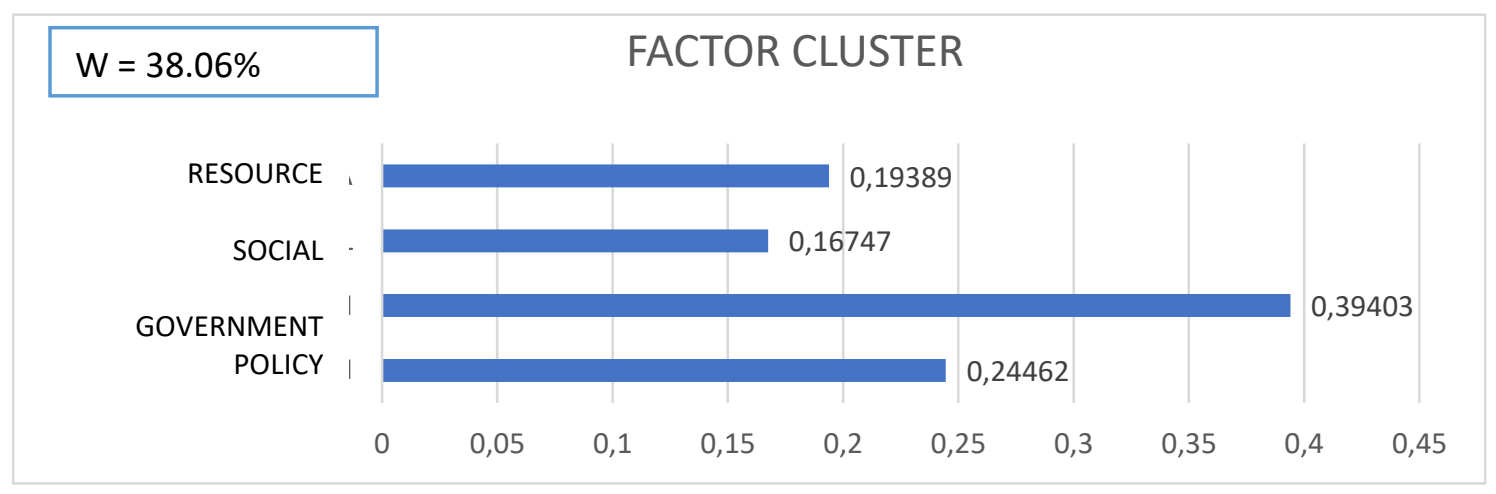

Figure 3. Synthesis Results of Factor Clusters Based on Geometric Mean Values

The result also aligns with Abdulai \& Regmi's (2000) research in his research. The role of government is particularly involved in increasing the costs of industrial production from the external side of agro-industries. As is proper research from Fasyah, Daryanto, \& Suprayitno (2016), regional governments are more likely to keep the market open by marketing incentives and cooperation with partners and industry quality to keep up with availability and improve the efficiency of the supply of raw materials.

\section{Resource factor problems}

Figure 4 shows that the main priority is resource factors in determining the downstream strategy for the leading processing industry is the problem of the large number of raw materials that have not been processed. These results represent the majority of respondents' answers with a value of $42.69 \%$. The lack of electrical energy sources is the second priority problem in determining the industrial downstream strategy with a percentage of $16.17 \%$, followed by a weakness in preserving resources and a lack of water supply by $15.30 \%$ and $14.86 \%$.

Meanwhile, the one that ranks last is the designation as a raw material producer area at $10.96 \%$. The result of obtaining the rater agreement of all respondents was $28.28 \%$. The level of respondents agreement on the order priority resource issues are the large number of raw materials that have not been processed, the lack of availability of electrical energy sources, a weakness in preserving resources, a lack of water supply, and the designation as a raw material producer area by $28.28 \%$. 


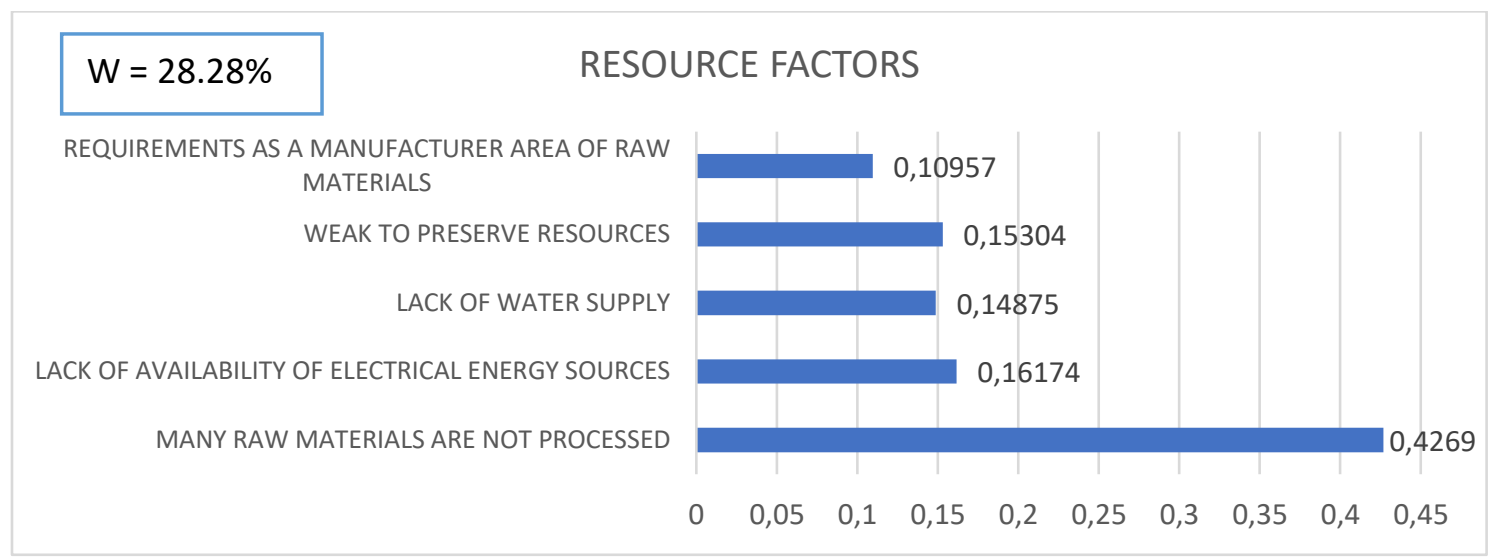

Figure 4. Synthesis results of resource factor priority problems based on the value of the geometric mean

The research aligns with Eriyatno (1993) that available raw material has an important role because it concerns the continuity of production and quantity of products. Mardiantony \& Ciptomulyono's (2012) research that uses the raw materials and available labor to increase production capacity is an appropriate strategy for prioritizing industrial subsector development.

\section{Economic factor problems}

Figure 5 shows the results of the synthesis of economic factor problems. The overall combination of respondents on average answers the main priority problems of economic factors in determining the downstream strategy of the leading processing industry, namely the limited government budget allocation for the industry with a percentage level of $19.61 \%$, followed by the problem of lack of availability of road infrastructure in good condition of $19.46 \%$.

Furthermore, the third and fourth ranks were land prices for factory locations, high at $18.76 \%$, and low investment (capital) for the industry at $16.60 \%$. The last two priorities are occupied by the provincial minimum wage and the limited market for industrial products amounting to $15.28 \%$ and $10.30 \%$, respectively. The result of obtaining the rater agreement of all respondents was $27.06 \%$. It means that the level of respondent agreement on the priority order of economic problems in the form of limited government budget allocations for industry, lack of availability of road infrastructure in good condition, the problem of high land prices for factory locations, low investment (capital) industry, provincial minimum wages, and limited market. Industrial products amounted to $27.06 \%$.

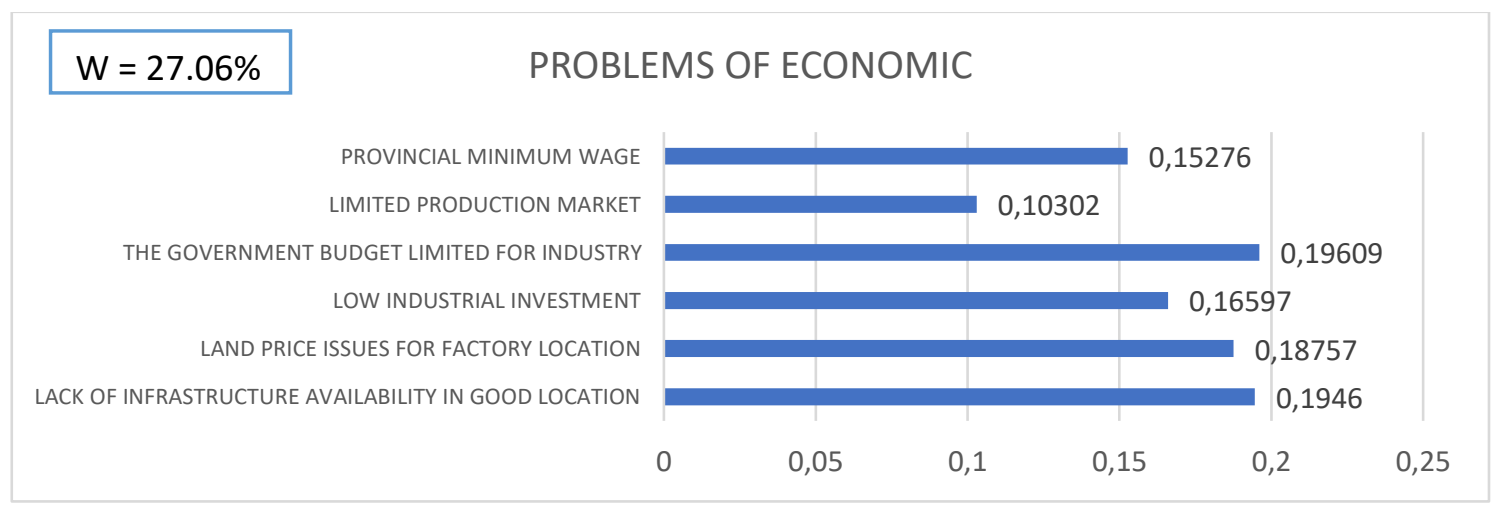

Figure 5. Results of the priority synthesis of economic factor problems based on the value of the geometric mean 
This study's results are different from Hakim's (2014) findings, which states that building facilities and infrastructure are the right strategies for industrial development to increase superior industrial growth. However, this research is supported by Hadiyanto \& Risman's (2015) research that government role as budgeting needs to be prioritized in industrial progress to boost exports an industry's competitive product of the manufacturing industry.

\section{Social factors problems}

Figure 6 shows the priority of resource factors. The social factor in determining a strategy to eliminate the seeded processing industry's top priority is the lack of tertiary institutions that provide industrial vocational education in $37.49 \%$, rather than by a lack of industrial technology capability in the area of $27.07 \%$. The third in the social factor problem is a limited skilled workforce in the industrial sector of $25.36 \%$. Furthermore, the last order for social factors is the local community's lack of support for the industry at $10.07 \%$. The result of the rater agreement value of all respondents was $22.50 \%$.

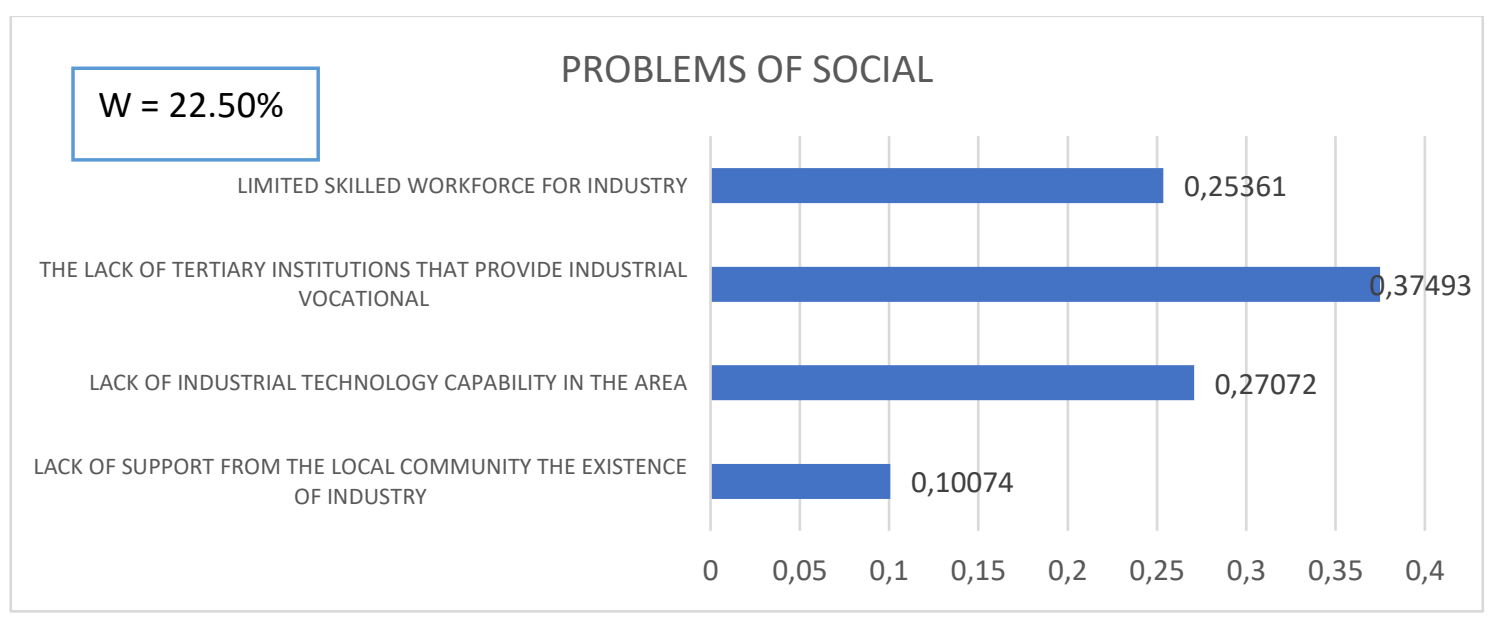

Figure 6. Synthesis results of social factors priority problems based on the value of the geometric mean

According to research by Wibowo \& Nugroho (2018) that growth in human resources through formal training and education is a labor-intensive work strategy that is appropriate for addressing industrial problems. As with Adhadika \& Pujiyono (2014), education positively and significantly impacts labor productivity.

\section{Local government policy factors}

Figure 7 shows the main priority of the problem of government policy factors in determining the downstream strategy for the leading processing industry was the lack of ease of industrial business licensing amounting to $27.37 \%$. Meanwhile, the second place in the priority problem of local government policy factors is the absence of industrial estates' determination at $24.15 \%$. Weak regional security and stability (land conflicts between companies and local communities) is the third priority at $19.86 \%$. The fourth priority is the presence of tax provisions and high tariffs of $15.42 \%$. Furthermore, with a percentage of $13.21 \%$, the last priority sequence is the absence of restrictions on the export and import of regional raw materials. The result from all respondents' rater agreement value in addressing local government policies' priorities is $27.36 \%$. 


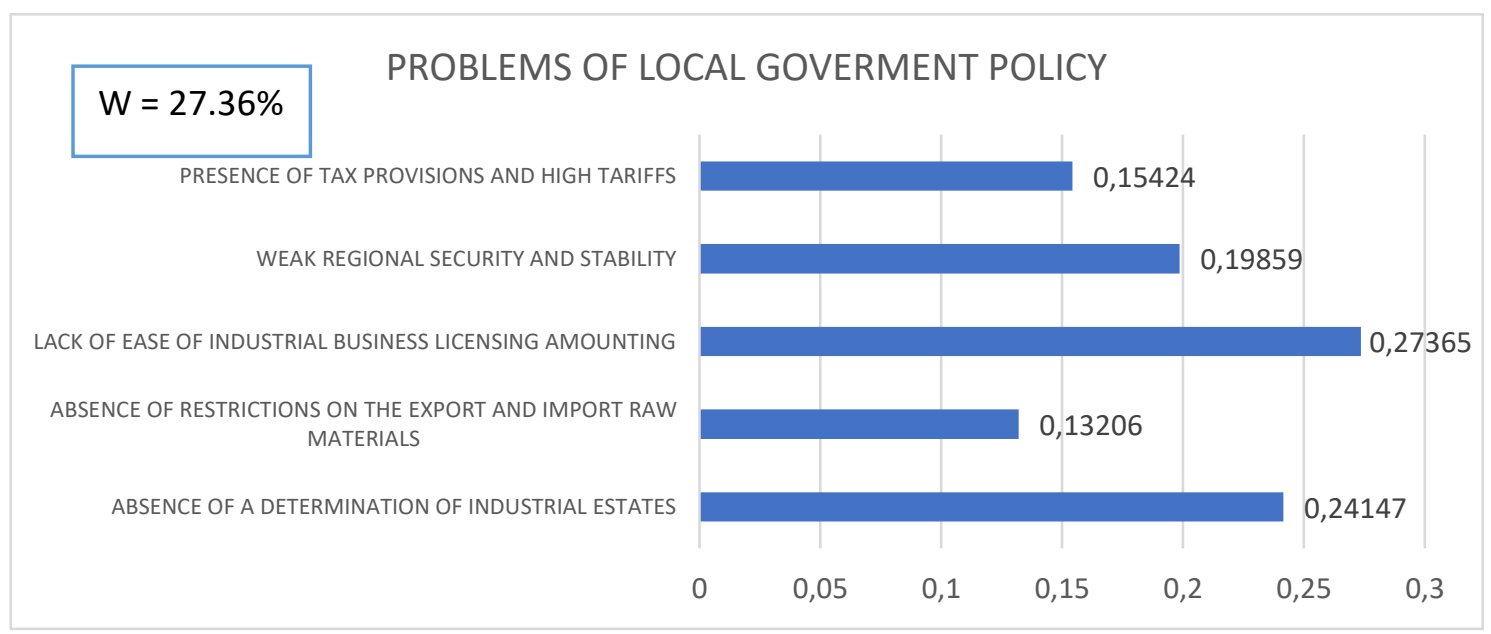

Figure 7. synthesis results of local government policy factors priority based on the geometric mean value

This research contradicts Winardi, Priyarsono, Siregar, \& Kustanto (2017), who found that industrial sectors located in industrial areas have a better performance in increasing the added value factors in labor and capital, thereby increasing people's income. However, this research is supported by Chandra and Ardianti (2014) the problem with lack of permit from industrial enterprises is a major problem that governments should provide socialization of easier access to informal sectors to enter the formal sector.

\section{Strategy cluster synthesis}

Figure 8 shows respondents' combined opinion about the most prioritized strategy for determining the leading processing industry's downstream strategy. The most prioritized strategy in determining the downstream strategy for the leading processing industry is optimizing the government's role in policies and funding for the downstream program by $34.62 \%$, followed by cross-sectoral coordination involving the business world for industrial downstream of $27.87 \%$. Carrying out construction and repair of infrastructure (roads, ports, and electric energy) is the third priority at $21.70 \%$. Furthermore, the last priority is the socialization of the existence (existence) of processed industrial products in the Jambi area of $15.80 \%$. The result of the rater agreement value of all respondents was $18.06 \%$.

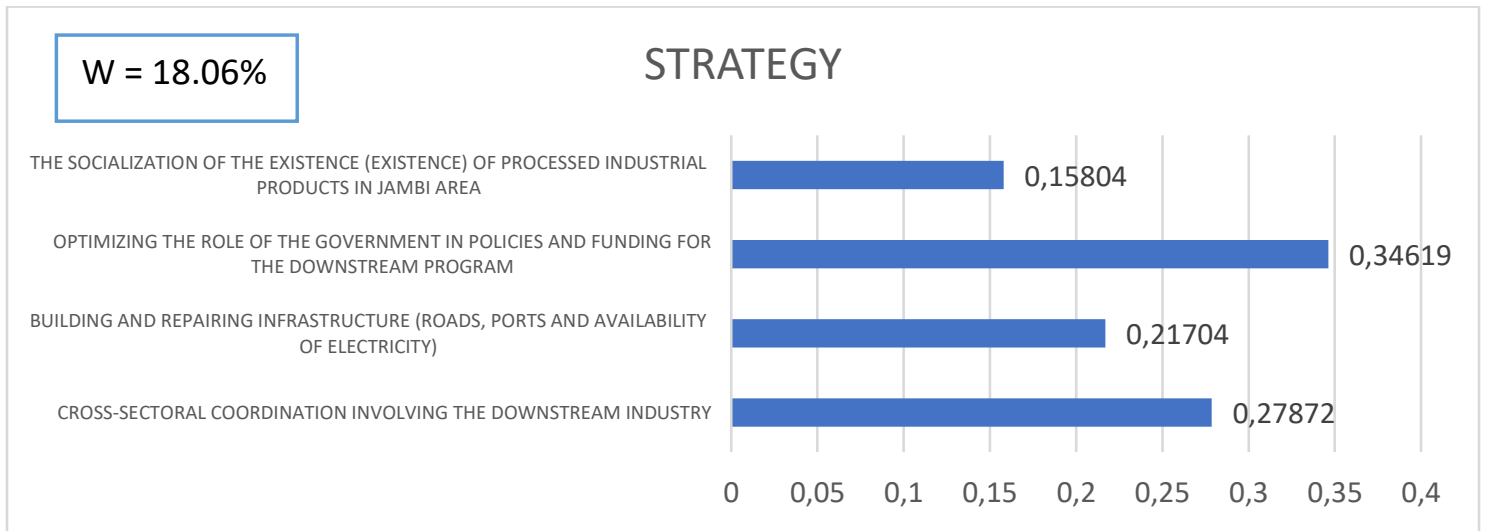

Figure 8. Synthesis results of strategy cluster priority based on geometric mean values

This study's results are following Nazara (2008), who stated that the role of government in formulating industrial development policies aims to provide new 
directions for future industrial development and overcome problems that hinder industrial development today. The strategy can be used to promote regional economic growth in Jambi Province through the downstream development of leading processing industries must have strong policies for downstream development of leading processing industries. The need for local government policies to regulate industrial processing areas by the suitability of regions/regions for industry, and differences in economic and social structures between districts/cities in Jambi province. According to one of the policies related to industrial estates mandated in Law no. 3 of 2014, every industrial company must be located in an industrial area (Winardi, 2019).

According to (Mulyadi, 2012), processing industries located in industrial areas will spur higher economic growth. The processing industry's location/area is fundamental to several production processes in the processing industry. There is a selection of locations based on proximity to raw material sources (raw material-oriented) such as the palm oil processing industry (CPO), paper industry, wood industry, etc. Market Oriented Industries such as the Food and Beverage Industry, Service and Repair Industry and so on and processing industries free or can be established anywhere (Foot Loose Industry) such as the textile industry etc. For this reason, the Jambi Provincial government policy must make and Prepare a clear and regular Road Map for the manufacturing sector in Jambi Province as a guide in the future development of the processing industry in Jambi Province.

\section{CONCLUSIONS AND RECOMMENDATIONS}

\section{Conclusions}

The priority strategies for the downstream development of the three processing industries in Jambi Province (the food and beverage industry, the paper and paper goods industry, and the rubber industry, rubber, and plastic goods) with a focus on regional government factors, namely optimizing the role of the government in policy and funding for the industrial downstream program processing. In contrast, the alternative strategy with the lowest priority is the socialization of the existence (existence) of industrially processed products in Jambi Province.

\section{Recommendations}

To implement the recommended strategy, cooperation between governments is needed in policy-making and all the downstream industry stakeholders (societies, industries, universities, and research institutions) to increase the growth of a high-value and competitive product to improve economic growth Jambi Province.

\section{REFERENCES}

Abdulai, A., \& Regmi, P.P. (2000). Estimating labor supply of farm households under nonseparability: empirical evidence from Nepal. Journal of Agricultural Economics, 22(3), 309-320.

Adhadika, T., \& Pujiyono, A. (2014). Analisis Faktor-Faktor Yang Mempengaruhi Produktivitas Tenaga Kerja Industri Pengolahan di Kota Semarang (Studi Kecamatan Tembalang Dan Kecamatan Gunungpati). Diponegoro Journal of Economics, 3(1), 1-13.

Andi. (2017). Strategy Selection to Increase Competitiveness of Textile Industry with ANP-BOCR Approach. Jurnal Arena Tekstil, 32(1), 9-16. 
Azis, I. J. (2003). Analytic Network Process with Feedback Influence: a new Approach to Impact Study, University of Illinoisat Urbana-Champaign: Department of Urban and Regional Planning.

BPS. (2019). Statistik Indonesia. Jambi: Badan Pusat Statistik.

Chandra, A., \& Ardianti, R. R. (2014). Faktor-Faktor Penghambat Pertumbuhan Usaha Mikro Dan Kecil Pada Sektor Formal Dan Informal di Jawa Timur. Jurnal AGORA, 2(1), 1-15.

Desfiando, B. (2014). Peran United Nations Industrial Development Organization (UNIDO) Dalam Membantu Perkembangan Industri Manufaktur Indonesia 20102013. Jom Fisip. 1(2).

Eriyatno., \& Sofyar, F. (1993). Riset Kebijakan Metode Penelitian Untuk Pascasarjana. Bogor: Institut Pertanian Bogor.

Fasyah, D. N., Daryanto, H. K., \& Suprayitno, G. (2016). Penentuan Produk Unggulan Usaha Mikro Kecil Menengah Sektor Industri Agro di Kabupaten Bogor. Jurnal Manajemen IKM, 11(2), 103-110.

Fauzi, A., Amir, A., Junaidi, J. \& Hidayat, S. (2019). Change of Economic Structure in Jambi Province: Input-Output Model Approach. Scientific Research Journal, 7(8), $62-72$

Hadiyanto \& Risman, Y. (2015). Pengaruh Diversifikasi Ekspor Terhadap Pertumbuhan Ekonomi Nilai Tambah Pertenaga Kerja Sektor Manufaktur Berbasis Agro dan non Agro. Buletin Ilmiah Litbang Perdagangan.

Hakim, L. (2015). Analisis Sektor Unggulan Prioritas dalam Pembangunan Ekonomi di Kabupaten Sumbawa Provinsi Nusa Tenggara Barat. [Masters Thesis], Universitas Negeri Sebelas Maret.

Hardiwan, D., Amir, A., Junaidi, J. \& Delis, A. (2019). The Linkages and Impact of Plantation-Based Sector on Economy and Poverty in Jambi Province, Indonesia: Miyazawa's Input-Output Model. Agricultural and Resource Economics: International Scientific E-Journal, 5(3), 5 - 19

Lucke, R \& Rowe, A.J (2006). Harvard Business Esentials: Decision Making : 5 Steps to Better Results. Boston: Harvard Business School Publishing.

Mardiantony, T. \& Ciptomulyono, U. (2012). Penerapan Analisis Input Output dan ANP dalam Penentuan Prioritas Pengembangan Sub Sektor Industri di Jawa Timur. Jurnal Teknik ITS, 1, 455-459.

Mulyadi, D. (2012). Manajemen Perwilayahan Industri. Jakarta: Kementerian Perindustrian.

Nazara, S. (2008). Sektor Industri Manufaktur dan Pembangunan Daerah. Jurnal Riset Industri, 2(3), 145-155.

Nila, K. (2014). Pengaruh Harga Minyak Mentah Dunia dan Tenaga Kerja Terhadap PDB Sektor Industri Pengolahan di Indonesia. Economic Development Analysis Journal UNNES, 3(1), 2252-6765.

Pike, A., Rodriguez, A., \& Tomaney, J. (2013). Local and Regional Development in the Global North and South. Progress in Development Studies. 14(1), 21-30.

Rusydiana, S.A. (2016). Analisis Masalah Pengembangan Industri Perbankan Syariah Di Indonesia : Aplikasi Metode-Analytic Network Process (ANP). Jurnal Bisnis \& Manajemen, 6(2), 2461-1182.

Sa'diyah, N. M., Komariyah, S., \& Hanim, A. (2017). Analisis Konsentrasi Spasial dan Strategi Pengembangan Industri Kecil di Jawa Timur. Jurnal Ekonomi Bisnis dan Akuntansi, IV(1), 58-62. 
Saaty, T. L. (2005). Theory and Applications of the Analytic Network Process: Decision Making with Benefits, Opportunities, Costs and Risks. RWS Publications,

Wibowo, S. A., \& Nugroho. (2018). Analisis Faktor-Faktor yang Mempengaruhi Produksi Industri Pengolahan dan Efisiensi Produksi pada Kabupaten/Kota di Jawa Tengah Tahun 2010-2015. Jurnal Ekonomi dan Manajemen, 33(2), 205-213.

Winardi. (2019). Role of Industrial Estate in Overcoming Deindrustialization. Jurnal of Economic and Developtment Indonesia, 19(1), 84-95.

Winardi., Priyarsono, D.S., Siregar, H., \& Kustanto, H. (2017). Kinerja Sektor Industri Manufaktur Provinsi Jawa Barat Berdasarkan Lokasi di Dalam dan di Luar Kawasan Industri. Jurnal Manajemen Teknologi, 16(3), 241-257.

(C) 2020 by the authors. Licensee JPPD, Indonesia. This article is an open-access article distributed under the terms and conditions of the Creative Commons Attribution (CC BY) license (http://creativecommons.org/licenses/by/4.0/). 